\title{
Application of Alkali Metal-Graphite Intercalation Compounds to Cryosorption Material for Hydrogen Isotopes
}

(Receivied Oct. 21, 1987)

\author{
N. Akuzawa*, K. Katano*, Y. Ohmura*, T. Konishi*, \\ T. Amemiya*, T. Terai** and Y. Takahashi** \\ * Tokyo National College of Technology, \\ 1220-2, Kunugida-machi, Hachioji-shi, Tokyo 193, Japan \\ ** Faculty of Engineering, University of Tokyo, \\ Hongo, Bunkyo-ku, Tokyo 113, Japan
}

Behavior of hydrogen absorption by alkali metal-graphite intercalation compounds (AM-GICs) at low temperatures was investigated in order to utilize them as a cryosorption material for hydrogen isotopes. The equilibrium hydrogen pressures at the condition where fractional absorption was 0.5 were determined to be 0.32 and 0.71 Torr for $\mathrm{CsC}_{24}$ and $\mathrm{RbC}_{\mathbf{2 4}}$, respectively, which were considerably low as compared with 32 Torr for $\mathrm{KC}_{24}$ and 83 Torr for molecular sieve 5A (MS 5A) under the same condition. Among AM-GICs, Cs-GIC was found to be the most promising because of low equilibrium pressure. Rb-GIC was also considered to be a good absorber. In contrast with the Langmuir type absorption observed for Cs- and Rb-GICs, K-GICs showed a complicated behavior, i.e. the characteristic sigmoid pressure dependence in its isotherm.

The effect of heat treatment temperature (HTT) of the pristine carbon material on the absorption behavior was also examined. In the case of Cs-GICs, the GIC sample prepared from well graphitized carbon material (with high HTT value) had larger absorption capacity of hydrogen absorption than those prepared from less graphitized one. On the contrary, K-GICs prepared from material with HTT of $1500^{\circ} \mathrm{C}$ showed maximum capacity of hydrogen absorption in low pressure region (below 1 Torr) among those prepared from materials with HTT of $1000,1500,2000$ and $2600^{\circ} \mathrm{C}$, although it was still inferior to Csand $\mathrm{Rb}$-GICs in absorbing ability of hydrogen gas.

\section{KEYWORDS: Graphite, Intercalation, Insertion, Hydrogen isotopes, Absorption}

\section{INTRODUCTION}

Alkali metal-graphite intercalation compounds (hereafter abbreviated as AM-GICs) have been known to absorb hydrogen gas at low temperatures $^{1), 2)}$. This phenomenon has been extensively studied. Lagrange et $a l .{ }^{3)}$ determined thermodynamic data for the hydrogen absorption by $\mathrm{KC}_{24}$. Lagrange and Hérold ${ }^{4}$ examined the effect of the starting carbon material of K-GICs on absorbing behavior of hydrogen gas and isotopic effect of the absorption of $\mathrm{H}_{2}$ and $\mathrm{D}_{2}$. Terai and Takahashi ${ }^{5), 6)}$ investigated the isotope separation of $\mathrm{HT}$ from $\mathrm{H}_{2}-\mathrm{HT}$ gas mixture by low temperature absorption on $\mathrm{KC}_{x}$. Maximum separation coefficient was obtained by the $\mathrm{KC}_{x}$ sample prepared from carbon material with heat treatment temperature of $1500^{\circ} \mathrm{C}$.

Metal-hydrogen systems are considered to be used in hydrogen storage ${ }^{7)}$. However there are still some difficulties remained. For example, hydrides are disintegrated into fine powdery form during hydrogen absorption-desorption cycles $^{8}$ ), and impurities in hydrogen gas such as oxygen reduce considerably the ability of hydrogen absorption ${ }^{9}$ ). In this respect, AM-GICs can be considered to be advantageous as a candidate material for hydrogen storage because 
of its relative immunity to disintegration by the repeated absorption-desorption cycling and to oxygen attack at working temperature. In order to examine the usefulness of AM-GICs as a cryosorption material, it is important to know that to what extent they can absorb hydrogen in low pressure region (below 1 Torr). Such data have not yet been reported. This paper aims at getting these data by measuring the absorption isotherm of hydrogen isotopes in low pressure region. In addition, the influence of starting carbon materials of AM-GICs upon the hydrogen absorption behavior is also investigated.

\section{EXPERIMENTAL}

\subsection{Materials}

Carbon materials used were Grafoil (Union Carbide Co., Ltd., GTA grade), cut into tips of about $30 \times 5 \times 0.4 \mathrm{~mm}$ and granular petroleum cokes with the particle size distributed from 0.18 to $0.25 \mathrm{~mm}$, heat-treated at $1000,1500,2000$ and $2600^{\circ} \mathrm{C}$ (hereafter abbreviated as HTT-1000, $-1500,-2000$ and -2600$)$. They were degassed at around $1000^{\circ} \mathrm{C}$ under a vacuum of $10^{-4} \mathrm{~Pa}$ before use. Alkali metals were used after purification by distillation.

\subsection{Preparation and characterization of AM- GICs}

AM-GICs were prepared by the usual two-bulb technique. The composition of the sample was determined by the weight increase after the preparation and/or by the chemical analysis being performed after finishing the hydrogen absorption experiments.

\subsection{Measurement of absorption isotherm}

The absorption isotherm was determined at temperatures of 77 and $90 \mathrm{~K}$ by the constant volume method ${ }^{6)}$. Special attention was given to obtain the precise data in low pressure region, lower than 1 Torr. Thus, the hydrogen gas pressure in low pressure range $\left(10^{-3}\right.$ Torr $<\mathrm{pH}_{2}<1$ Torr) was measured by a McLeod gauge. At high pressures above 1 Torr, a conventional mercury manometer was used. It was confirmed that the rate of hydrogen absorption was fairly rapid and around $20 \mathrm{~min}$ was enough to reach the equilibrium of absorption. Therefore, the equilibrium pressure, denoted as $p_{e q}$, was taken after being allowed to stand for $30 \mathrm{~min}$. The fractional absorption, $\theta$, was defined by the absorbed amount of hydrogen normalized by saturated amount at high equilibrium pressure. When we need to compare the results of different conditions, we used relative equilibrium pressure, Peq $/$ Peq $(\theta=0.5)$ normalized by Peq at $\theta=0.5$.

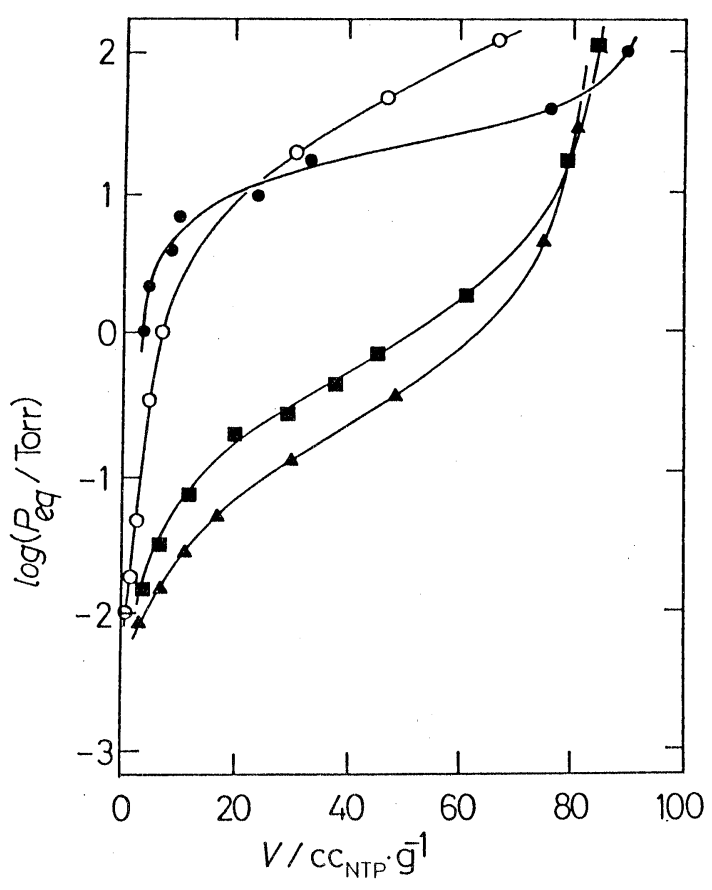

Fig. 1 Absorption isotherms of hydrogen at 77 $\mathrm{K}$ by $\mathrm{KC}_{21.3}(\bullet), \mathrm{RbC}_{23.2}(-), \mathrm{CsC}_{23.8}(\mathbf{\bullet})$ and $\operatorname{MS} 5 \mathrm{~A}(0)$ as $\log \left(\mathrm{p}_{\text {eq }} /\right.$ Torr $)$ vs. $\mathrm{V} / \mathrm{cc}_{\mathrm{NTP}} \cdot \mathrm{g}^{-1}$ plots.

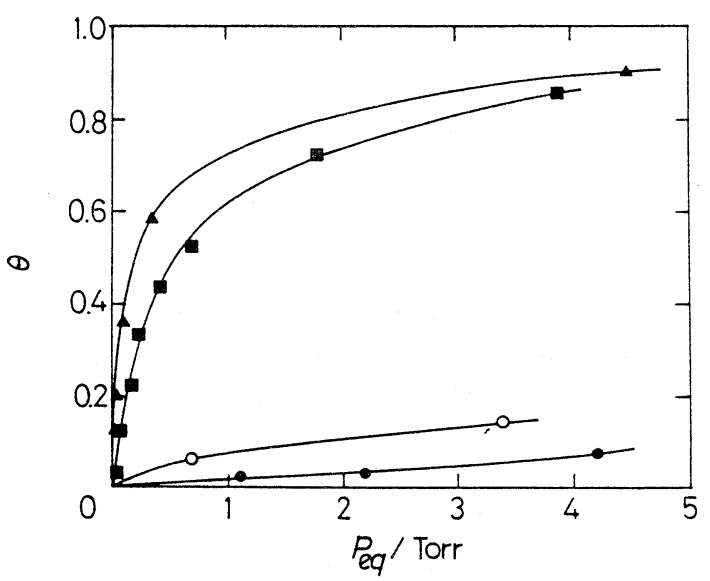

Fig. 2 Fractional absorption $\theta$ vs. peq plots: $\bullet, \mathrm{KC}_{21.3} ; \bowtie, \mathrm{RbC}_{23.2} ; \mathbf{4}, \mathrm{CsC}_{23.8}$; $\circ$, MS5A. 


\section{RESULTS AND DISCUSSION}

\subsection{Isotherms for $\mathrm{K}-$, Rb- and Cs-GICs}

Absorption isotherms of hydrogen gas by $\mathrm{KC}_{21.3}, \mathrm{RbC}_{23.2}$ and $\mathrm{CsC}_{23.8}$ at $77 \mathrm{~K}$ are shown in Fig. 1 in the form of $\log \left(\mathrm{p}_{\mathrm{eq}} /\right.$ Torr $)$ vs. (V/ $\left.\mathrm{cc}_{\text {NTP }} \cdot \mathrm{g}^{-1}\right)$. GIC samples used were prepared from Grafoil. In the figure the data for MS $5 \mathrm{~A}$ (molecular sieve 5A, synthetic zeolite) are also plotted for the comparison. The equilibrium pressures $\mathrm{peq}_{\text {eq }}$ for $\mathrm{CsC}_{23.8}$ and $\mathrm{RbC}_{23.2}$ are much lower than for $\mathrm{KC}_{21.3}$ and $\mathrm{MS} 5 \mathrm{~A}$ in low pressure region, which suggest advantage of $\mathrm{Cs}$ - and Rb-GICs in the absorption of $\mathrm{H}_{2}$ gas. The absorption capacities per 1 gram of GIC for $\mathrm{CsC}_{23.8}$ and $\mathrm{RbC}_{23.2}$ at 1 Torr are about 10 times larger than that for $\mathrm{KC}_{21.3}$ and $\mathrm{MS} 5 \mathrm{~A}$. This is more clearly seen in Fig. 2, where fractional absorption $\theta$ is plotted against pressure in low pressure region. The equilibrium hydrogen pressures $P_{e q}$ at the fractional absorption $\theta$ of 0.2 and 0.5 are shown in Table 1 for $\mathrm{KC}_{21.3}$, $\mathrm{RbC}_{23.2}, \mathrm{CsC}_{23.8}$ and MS 5A.

Table 1 Equilibrium pressure $p_{e q}$ at fractional absorption $\theta$ of 0.2 and 0.5 .

\begin{tabular}{cccc}
\hline \multirow{2}{*}{ GIC } & $\begin{array}{c}\text { gas } \\
\text { absorbed }\end{array}$ & \multicolumn{2}{c}{$\begin{array}{c}\text { Equilibrium pressure } \\
\mathrm{p}_{\mathrm{eq}} \text { */Torr }\end{array}$} \\
\cline { 3 - 4 } & & $\theta=0.2$ & $\theta=0.5$ \\
\hline Cs-GIC & $\mathrm{H}_{2}$ & 0.05 & 0.32 \\
& $\mathrm{D}_{2}$ & 0.04 & 0.25 \\
Rb-GIC & $\mathrm{H}_{2}$ & 0.16 & 0.71 \\
& $\mathrm{D}_{2}$ & 0.05 & 0.20 \\
K-GIC & $\mathrm{H}_{2}$ & 8.9 & 32 \\
MS 5A & $\mathrm{H}_{2}$ & 11 & 83 \\
\hline
\end{tabular}

* at $77 \mathrm{~K}$

The observed difference in the absorption behavior between AM-GICs used may be explained as follows. The isotherms of hydrogen absorption by $\mathrm{MC}_{24}(\mathrm{M}=\mathrm{K}, \mathrm{Rb}, \mathrm{Cs})$ at $77 \mathrm{~K}$ are replotted in Fig. 3 as $\theta$ vs. peq $/ \mathrm{p}_{\text {eq }}(\theta=0.5)$. All the data for $\mathrm{CsC}_{24}$ and $\mathrm{RbC}_{24}$ fall on a single line given by Langmuir equation. On the other hand, the data for $\mathrm{KC}_{24}$ deviate significantly from this line. It is reported ${ }^{2)}$ that in the course of hydrogen absorption interplanar distance

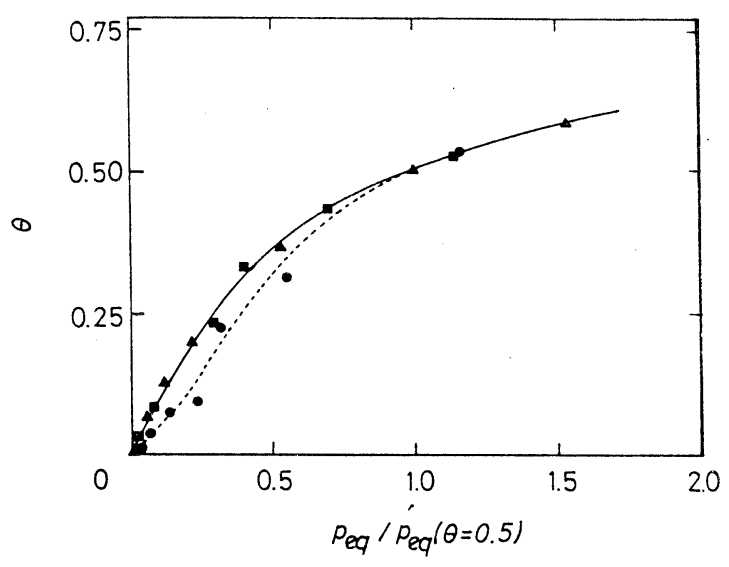

Fig. 3 Absorption isotherms of hydrogen at $77 \mathrm{~K}$ by $\mathrm{KC}_{21.3}(\bullet), \mathrm{RbC}_{23.2}(-)$ and $\mathrm{CsC}_{23.8}(\mathbf{\Delta})$, where equilibrium pressure is expressed by $\mathrm{p}_{\mathrm{eq}} / \mathrm{p}_{\mathrm{eq}}(\theta=0.5)$, that is, equilibrium pressure normalized by that at $\theta=0.5$.

along the c-axis increases from $5.4 \AA$ for $\mathrm{KC}_{24}$ to $5.69 \AA$ for $\mathrm{KC}_{24}\left(\mathrm{H}_{2}\right)_{2}$, while those of $\mathrm{CsC}_{24}$ or $\mathrm{RbC}_{24}$ are effectively unaltered. Therefore $\mathrm{KC}_{24}$ needs extra energy for expanding along c-axis. If this extra energy is fairly large, we may observe a threshold pressure as seen in absorption of methane by $\mathrm{CsC}_{24}{ }^{2)}$. In the case of hydrogen absorption by $\mathrm{KC}_{24}$, it is considered that the extra energy is not too large to induce the threshold, but it causes sigmoid pressure dependence of $\mathrm{H}_{2} / \mathrm{K}$ observed here.

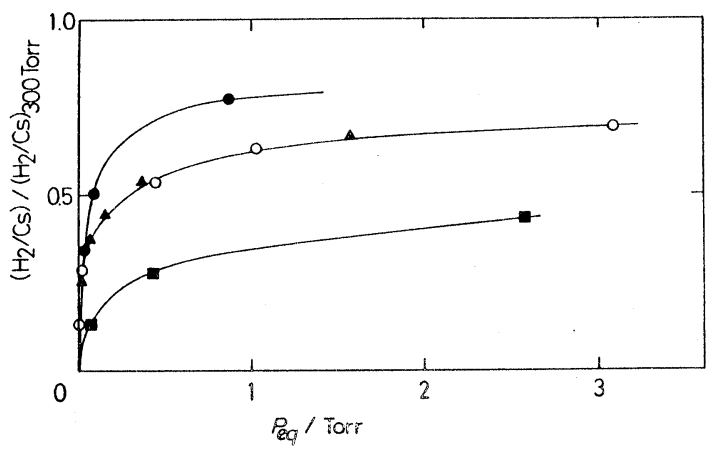

Fig. $4\left(\mathrm{H}_{2} / \mathrm{Cs}\right) /\left(\mathrm{H}_{2} / \mathrm{Cs}\right)_{300}$ Torr vs. peq plots for $\mathrm{CsC}_{x}: \mathbf{H T T}-1000\left(\mathrm{CsC}_{43.9}\right)$;

O, HTT-1500 ( $\left.\mathrm{CsC}_{28.7}\right)$;

A, HTT-2000 ( $\left.\mathrm{CsC}_{33.6}\right)$;

•, $\mathrm{HTT}-2600\left(\mathrm{CsC}_{37.1}\right)$. 


\subsection{Effect of heat treatment of carbon materials}

In order to compare the effect of the heat treatment temperature (HTT) of pristine carbon materials on the absorption behavior, cesium and potassium GICs were prepared from granular petroleum cokes of HTT-100, 1500, 2000 and 2600. Their absorption isotherms in low pressure region are shown in Fig. 4 for Cs-GIC and Fig. 5 for K-GIC, respectively, where the amounts of $\mathrm{H}_{2}$ absorbed were normalized by those at the pressure of 300 Torr for each sample. It can be seen from Fig. 4 that as heat treatment temperature (HTT) of the pristine material increases the amount of $\mathrm{H}_{2}$ absorbed increases steeply with pressure. Thus the well graphitized material is advantageous to give large capacity of hydrogen absorption to the resulting $\mathrm{CsC}_{24}$.

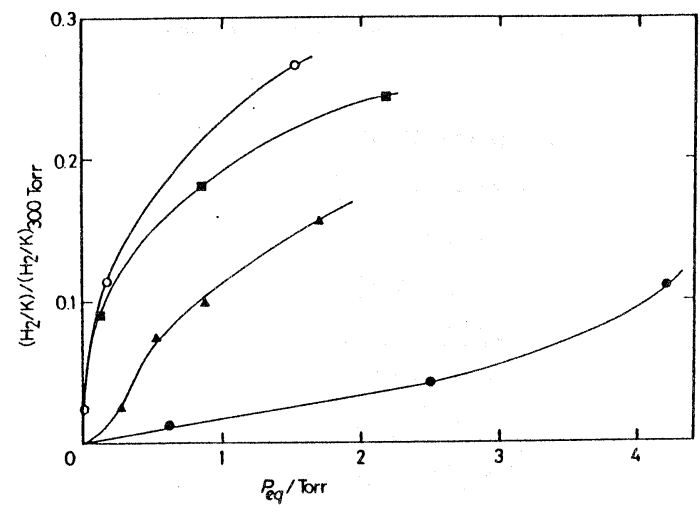

Fig. $5\left(\mathrm{H}_{2} / \mathrm{K}\right) /\left(\mathrm{H}_{2} / \mathrm{K}\right)_{300}$ Torr vs. peq plots for $\mathrm{KC}_{x}: \mathrm{HTT}-1000\left(\mathrm{KC}_{15.7}\right)$;

○, $\mathrm{HTT}-1500\left(\mathrm{KC}_{19.8}\right)$;

4, $\mathrm{HTT}-2000\left(\mathrm{KC}_{19.4}\right)$;

-, HTT-2600 $\left(\mathrm{KC}_{15.5}\right)$.

In the case of $\mathrm{KC}_{24}$, on the contrary, the maximum capacity of hydrogen absorption is attained by HTT-1500 material as shown in Fig. 5. As HTT decreases the sigmoid pressure dependence is tend to be modified towards Langumuir type. It is interesting to note that the similar behavior has been observed in the isotope separation phenomena in the absorption of $\mathrm{H}_{2}$ $\mathrm{D}_{2}$ gas mixture by K-GIC: The maximum isotope separation coefficient for $\mathrm{H}_{2}-\mathrm{D}_{2}$ and $\mathrm{H}_{2}-\mathrm{HT}$ gas mixture was attained by $\mathrm{KC}_{12}$ prepared from HTT-1500 $^{\text {material }}{ }^{5), 6)}$. Furthermore, the remarkable reactivity of $\mathrm{KC}_{8}$ prepared from HTT-
1500 material against water vapor has been reported ${ }^{10)}$. Such observations sustain that somewhat disordered structure is advantagenous to give large capacity of hydrogen absorption to resulting $\mathrm{KC}_{24}$. It has to be mentioned that although $\mathrm{KC}_{24}$ prepared from HTT-1500 material showed somewhat increase in hydrogen absorption capacity, the fractional absorption at 1 Torr is still $1 / 3 \sim 1 / 4$ times of that for $\mathrm{CsC}_{2} 4$ prepared from HTT-2600 material.

Absorption rate by $\mathrm{CsC}_{24}$ prepared from HTT-2600 material is quite fast and virtually absorption equilibrium is attained in a few minutes. In addition, this $\mathrm{CsC}_{24}$ sample did not show any indications of disintegration by the 20 times of repeated absorption-desorption cycling. This is in contrast to metal-hydrogen system in which disintegration by the repeated absorptiondesorption cycling has been recognized to be a serious problem ${ }^{8}$.

\section{CONCLUSION}

(1) Absorption of hydrogen by $\mathrm{MC}_{24}(\mathrm{M}=\mathrm{K}$, $\mathrm{Rb}, \mathrm{Cs}$ ) at $77 \mathrm{~K}$ was investigated in order to apply $\mathrm{MC}_{24}$ as a cryosorption material for hydrogen isotopes. It was found that $\mathrm{CsC}_{24}$ is the most promising as a cryosorption material.

(2) As HTT increased, amount of $\mathrm{H}_{2}$ absorption in low pressure region increased for $\mathrm{CsC}_{24}$. In the case of $\mathrm{KC}_{24}$, on the contrary, the maximum capacity of hydrogen absorption was attained by HTT- 1500 material.

\section{Acknowledgement}

This work was supported in part by Grant in Aid for Scientific Research of Japanese Government, Project No. 62550572.

\section{References}

1) K. Watanabe, M. Soma, T. Onishi and K. Tamaru, Nature Phys. Sci. 233, 160 (1971)

2) K. Watanabe, T. Kondow, M. Soma, T. Onishi and K. Tamaru, Proc. Roy. Soc. Lond. A333, 51 (1973)

3) P. Lagrange, A. Metrot and A. Herold, C. R. Acad. Sci. Paris C275, 765 (1972)

4) P. Lagrange and A. Herold, C. R. Acad. Sci. Paris C281, 381 (1975)

5) T. Terai and Y. Takahashi, J. Nucl. Sci. 
Technol. 18, 643 (1981)

6) T. Terai and Y. Takahashi, Carbon 22, 91 (1984)

7) J. J. Reilly, Z. Phys. Chem. N. F. 117, 155 (1979)

8) H. Ishikawa, K. Oguro, A. Kato, H. Suzuki and E. Ishii, J. Less-Common Metals 107, 105 (1985)
9) T. Hirata, J. Less-Common Metals 107, 23 (1985)

10) N. Akuzawa, T. Seino, A. Yugeta, T. Amemiya and Y. Takahashi, Carbon 25, 691 (1987)

\section{炭素材料学会編}

炭素材料アドバンスドシリーズＮo． 1

\section{炭素繊維の展開と評価方法}

著者 松井醇一氏 (東レ(侏) A C M技術部部長) A 5 判 300 頁 昭和63年 9月発刊予定 炭素材料学会員特別価格

$$
\text { 6. } 000 \text { 円（送料 } 350 \text { 円） }
$$

定価 7.800 月(送料 350 円)

\section{第 1 章 炭素緎維の発展}

1. 炭素㵶維の発明から量産まで

2. 炭素繊維の用途の展開

3. C F R P の性質

4. 1 次構造部材としての C F R P - 再弱層 設計思想の基礎

5. 次世代複合材料の展望

第2 章 炭素緎維およびその複合材料の品質管理

1. 品質管理制度の発展

2. 品質管理制度の内容

3. 品質管理制度の運用

4. C F R P の品質安定化のために

第 3 章 標準化

1. 炭素繊維試験方法標準化の歴史

2. 日本の現状

3. 米国の現状

4. 欧州の現状

5. 国際的な活動

6. 標準化の問題点
第4 章 炭素繊維の評価方法

1. 炭素㵶維用語の意味

2. 炭素繊維の形態

3. 炭素繊維の構造

4. 炭素緎維の化学組成

5. 炭素綫維の表面

6. 炭素繊維の機械的性質

7. 炭素繊維の熱的性質

8. 炭素㵶維の電気的性質

9. 炭素㵶維の化学的性質

\section{予約受付中}

ご希望の方は，「炭素繊維の展開と評価方 法』と題記して,（1）住所, (2) 勤務先の名称・ 所属部課名, 所在地, 電話番号, (3) 氏名 をご 記入の上，はがきまたは F A Xにてお申し込み下 さい。できあがり次第, 現品に請求書を添えてご 送付いたします。

申込先 : 㑣リアライズ社

東京都文京区湯島 2-16-13 齐藤ビル $2 \mathrm{~F}$ ₹113 電 話 $03-815-8511$ FAX $03-815-8529$ 